\title{
LOS DISCURSOS DE LA GUERRA EN LA GRAN CRÓNICA DE ALFONSO XI
}

\author{
Fernando Arias Guillén ${ }^{I}$
}

\section{RESUMEN:}

La cronística medieval proporciona una información valiosísima a la hora de estudiar las distintas imágenes y representaciones que el poder proyectaba sobre sí mismo. En ese sentido, la guerra constituye un tema de especial interés, pues era uno de los fenómenos que más atención recibía en los relatos y una de las principales fuentes de legitimación de la institución regia. Así pues, se ha analizado la Gran Crónica de Alfonso XI no por su valor documental, sino en base a los distintos discursos que la Monarquía transmitía en relación con la actividad bélica. Por un lado, se buscaba justificar y legitimar las distintas campañas que la Corona auspiciaba, y, por otro, se intentaba idealizar la figura de Alfonso XI en base su política militar. Las interrelaciones pasado-presente serían una pieza clave en este entramado ideológico.

Palabras Clave: Reino de Castilla. Alfonso XI. Monarquía. Crónicas. Ideología. Guerra. Reconquista.

\section{ABSTRACT:}

Mediaeval Chronicles provide very valuable information in order to study the different images and representations that the Power projected of itself. In this sense, War constitutes a topic of special interest, since it was one of the phenomena that received more attention and one of the principal sources of legitimization of the royal institution. So, the Gran Crónica de Alfonso XI has been analyzed not by its documentary value, but on the basis of the different discourses that the Monarchy was transmitting related to warfare. On one hand, it was seeking to justify and to legitimize the different campaigns that the Crown was supporting, and, on the other hand, it tried to idealize the figure of Alfonso XI in base of his military policy. The correlations past - present would be a key piece in this ideological structure.

Keywords: Castile. Alfonso XI. Monarchy. Chronicles. Ideology. War. Reconquest.

1 Instituto de Historia. CSIC. Madrid. Email: farias@ih.csic.es. Este artículo se inscribe en la beca predoctoral FPU, concedida por el Ministerio de Educación y Ciencia, cuyo número de referencia es AP2006-1585. 


\section{INTRODUCCIÓN}

El reinado de Alfonso XI cuenta con una notable riqueza cronística, pues hay hasta tres grandes obras narrativas para este período: la Gran Crónica de Alfonso XI, la Crónica de Alfonso XI y el Poema de Alfonso XI ${ }^{2}$. No obstante, su valor como fuente documental ha hecho que los historiadores olviden su análisis como texto histórico ${ }^{3}$.

Éste adquiere entidad en sí mismo pues no sólo es un artefacto literario o una narración fáctica, sino que realiza una función de enorme interés: es el intermediario entre el presente desde el que se hilvana y el pasado que trata de evocar. Desde esta perspectiva, el medievalismo español ha prestado poca atención al estudio de las crónicas ${ }^{4}$.

La época del Onceno no es una excepción, pues los únicos análisis recientes en esta línea han sido los de Purificación Martínez ${ }^{5}$ y Ana Belén Paniagua ${ }^{6}$, quienes analizaron los distintos discursos políticos respecto a la monarquía, la figura real y la visión de los musulmanes. Por ello, resulta pertinente detenerse en analizar uno de los aspectos a los que la Gran Crónica prestó más atención: la guerra contra los poderes islámicos ${ }^{7}$, pues "dos cosas la mas prinçipales que Dios le encomendo (a Alfonso XI) en el rreyno, la una la justiçia, e la otra la guerra contra los moros".

2 Se ha utilizado esta crónica en particular pues goza de una excelente edición crítica, realizada por el profesor Diego Catalán (Gran Crónica de Alfonso XI, Madrid: Gredos, 1977, dos vols.). Además, con la salvedad que la Gran Crónica termina su narración tras la victoria del Salado, es mucho más prolija en detalles de las campañas, ya que incluye más discursos y reflexiones de los principales protagonistas. Purificación Martínez (en "La Crónica y la Gran Crónica de Alfonso XI: dos versiones ideológicas del reinado de Alfonso XI", Hispanic Research Journal: Iberian and Latin American Studies, vol. 1, nº 1 (2000), pp. 43-56) considera que las modificaciones, principalmente la inclusión de capítulos adicionales, que sufrió este manuscrito respecto al más antiguo (La Crónica de Alfonso XI), socavan la imagen del poder real que Fernán Sánchez de Valladolid intentó modelar. No obstante, considero esta idea bastante taxativa. Las diferencias que la autora analiza se dan en el enfrentamiento entre don Juan Manuel y el monarca, por lo que pienso que el principal motivo de los cambios es justificar la actuación concreta de este personaje, no alterar la imagen regia, pues el texto fue escrito durante el reinado de Enrique II (en torno a 1376-1379), cuya esposa era Juana Manuel. Diego Catalán reseña la simpatía que el autor de la Gran Crónica muestra por el magnate, en contraste con la manifiesta hostilidad del Canciller en el manuscrito originario. A su vez, afirma y reconoce la existencia de dos actitudes históricas contradictorias en el texto, pero no lleva tan lejos su razonamiento. En cualquier caso, considero que el discurso e intencionalidad primigenios que la Monarquía deseaba transmitir pueden detectarse en esta versión, aunque haya sufrido interpolaciones y motivos como el honor o la religión aparezcan de manera más recurrente que en la primera obra.

3 MARTÍNEZ, P.: "La Crónica y la Gran Crónica de Alfonso XI...”" p. 44.

4 AURELL, J.: "El nuevo medievalismo y la interpretación de los textos históricos", Hispania, 224 (2006), pp. 813-819 y 831. Para un desarrollo más completo de la relación pasado-presente en las crónicas me remito a GÓMEZ REDONDO, F., Historia de la prosa medieval castellana. I La creación del discurso político: el entramado cortesano, Madrid: Cátedra, 1998.

5 MARTÍNEZ, P.: "La Crónica y la Gran Crónica de Alfonso XI: dos versiones ideológicas del reinado de Alfonso XI", Hispanic Research Journal: Iberian and Latin American Studies, vol. 1, n 1 (2000), pp. 43-56 y "La historia como vehículo político: la figura real en la Crónica de Alfonso XI", Espacio, tiempo y forma. Serie III, 13 (2000), pp. 215-231.

6 PANIAGUA LOURTAU, A. B.: "Consideraciones sobre los musulmanes en la Gran Crónica de Alfonso XI”, en TORO CEVALLOS, F. y RODRÍGUEZ MOLINA, J. (coord.), Historia, tradiciones y leyendas en la frontera: IV estudios de Frontera: congreso celebrado en Alcalá la Real en noviembre de 2001: homenaje a Don Enrique Toral y Peñaranda, 2002, pp. 417-430.

7 Cuantitativamente es el tema más recurrente, véase el cómputo de páginas que realizó el profesor Rojas Gabriel en: "La batalla en la Edad Media y su contexto estratégico. El choque del Salado (1340), reexaminado", en González Jiménez, M. (ed.), Tarifa en la Edad Media, Tarifa: Excmo Ayuntamiento de Tarifa, 2005 , p. 151 (aparece reflejado en una nota al pie).

8 CATALÁN, D., Gran Crónica de Alfonso XI...vol. I, p. 397. 
En relación con este tema, son muchos los aspectos que podrían ser motivo de reflexión: las imágenes guerreras que la cronística proyecta sobre la figura regia, el papel del conflicto como fuente de legitimación de la Monarquía, o los motivos que la Corona aducía para justificar las distintas campañas en las que se embarcó y hacerla presentable a ojos de la sociedad castellana. Este último aspecto será sobre el ahondará el presente trabajo, aunque se pondrá en relación con las ideas anteriores.

\section{GUERRA JUSTA Y GUERRA SANTA}

Un rey "no deve comenzar la guerra sin grant culpa o merecimiento de aquel su contrario", por lo que "a mester que tenga derecho et que lo non faga con tuerto nin con sobervia".

De este modo, cualquier guerra debía ser "justa", pues, en muchas ocasiones, era interpretada desde un punto de vista más jurídico que político o estratégico ${ }^{10}$. En la tradición occidental, sería San Agustín quien estableciera su legitimidad, debiendo ser motivada por una causa apropiada, dirigida por una autoridad constituida y con el propósito de establecer la paz y el orden. Asimismo, existía el natural derecho a defensa frente a agresiones y realizar acciones ofensivas contra quienes hubieran causado un daño o para recuperar algo tomado injustamente ${ }^{11}$.

Durante el siglo XI, y unida a la reforma cluniacense, se gestó la noción de Guerra Santa. Así pues, cualquier enfrentamiento contra herejes, paganos o infieles estaba justificado, pues se hacía en defensa (y expansión) de la religión y de la Christianitas. Aunque hay acuerdo en el mundo académico para establecer los paralelos cronológicos entre la expansión del monacato de Cluny y la gestación de las Cruzadas, no hay consenso a la hora de establecer esta relación, pues algunos autores consideran el nacimiento de este fenómeno como algo exógeno al Occidente latino, una respuesta a la Yihad islámica y al peligro musulmán ${ }^{12}$.

De este modo, la Guerra Justa estaba relacionada con la legitimidad y la Guerra Santa con un fundamento religioso, aunque resulta difícil su distinción, ya que estaban íntimamente ligadas ${ }^{13}$.

Esta imbricación fue aún más acusada en la Península, donde no ha habido acuerdo a la hora de establecer la naturaleza ideológica de esta lucha, mezclada o enfrentada a la idea de Reconquista. Ambas nociones confluyeron a partir del siglo XI, aunque su origen y características eran distintos ${ }^{14} \mathrm{y}$, a partir de la victoria de Las Navas, la historiografía peninsular las ligó definitivamente ${ }^{15}$.

9 MACPHERSON, I. R. y TATE, R. B., (eds.), El libro de los Estados, Madrid: Castalia, 1991, p. 214 y 217.

10 GARCÍA FITZ, F., Edad Media. Guerra e ideología. Justificaciones jurídicas y religiosas, Madrid: Sílex, 2003, p. 25.

11 O’CAllaghaN, J. F., Reconquest and Crusade in Medieval Spain, Philadelphia: University of Pennsylvania, 2003, p. 13.

12 CANTARINO, V.: “The Spanish Reconquest: A Cluniac Holy War against Islam?”, en Khalil I. Semaan (ed.), Islam and the medieval West. Aspects of Intercultural relations: papers presented at the Ninth Annual Conference of the Center for Medieval and Early Renaissance Studies State University of New York at Binghamton, Albany: State University of New York Press, 1980, pp. 82-83.

13 GARCÍA FITZ, F., Edad Media. Guerra e ideología...pp. 17-18.

14 GARCÍA FITZ, F., Las Navas de Tolosa, Madrid: Ariel, 2005, p. 393.

15 RODRÍGUEZ LÓPEZ, A.: "Légitimé royale et discours de la croisade en Castille. XIIe-XIIIe siècles”, Journal des Savants, 2004 / I, p. 152. 
Cruzada y Reconquista fueron los leit-motivs más comunes que la cronística castellana esgrimió para justificar su expansión a costa de los distintos poderes islámicos. En la Gran Crónica de Alfonso XI aparecía además otro elemento recurrente, el honor ${ }^{16}$.

No obstante, la guerra contra los musulmanes se admitía como algo legítimo y normal ${ }^{17}$, por ejemplo, el Onceno ordenó, en una misiva de 1327, al concejo de Lorca que "fagades guerra contra los moros, la mas crua et la mas afincada que podierdes"18. No necesitaba ninguna explicación ni justificación ideológica, pues era una actividad sumamente común. De igual modo, y pese a la especial querencia del monarca por las armas y la actividad bélica, "las crónicas presentan la guerra no como un hábito profesional o una inclinación personal, sino una obligación histórica surgida por la presencia de un enemigo continuo"19. En 1315, tras las Cortes de Burgos, el Infante Pedro partía a la Frontera rutinariamente "por rrazon de la guerra de los moros". De igual modo, antes de comenzar su primera campaña, el cronista se detuvo en vincular la labor de Alfonso XI con la de los reinados anteriores, apareciendo como continuador de una tarea insoslayable ${ }^{20}$.

Pese a ello, la Corona consideró oportuno exponer una serie de motivos que revistieran de legitimidad sus acciones bélicas. Éstos no se aplicaron de manera sistemática, sino que aparecieron salpicados por el texto, incluso a veces de manera que puede antojarse contradictoria. El momento en que se condensaron, y se apeló a ellos de manera recurrente, fue en la batalla del Salado, el momento álgido del reinado y el gran éxito del Onceno, por lo que se cargaron las tintas en su importancia. Éste no sólo continuó la tarea de sus ancestros o luchó en defensa de la fe, como buen príncipe cristiano, sino que venció a la mayor amenaza que se cernía, no únicamente ante su reino, sino sobre la Cristiandad entera, salvándola de la perdición ${ }^{21}$.

Una vez planteados los aspectos generales, es momento de detenerse en cada uno de los motivos ideológicos que recorren la obra.

\section{GUERRA Y RELIGIÓN: ENTRE LA CRUZADA Y LA ORDALÍA}

La Cruzada puede definirse como una Guerra Santa indulgenciada, en la que los pecados se remiten por participar en la $\operatorname{misma}^{22}$. La victoria del Salado y otras cam-

16 Junto a estos motivos ideológicos, aparecen otros más "pragmáticos" como pueden ser la defensa del reino o el servicio al monarca. Sería interesante reflexionar sobre el uso de unos u otros en distintos momentos o en diversos tipos de documentación, pero esta pregunta escapa a los planteamientos del trabajo y a su extensión.

17 LOMAX, D., La Reconquista, Barcelona: Crítica, 1984, p. 136.

18 VEAS ARTESEROS, F., Colección de documentos para la historia del Reino de Murcia. VI Documentos de Alfonso XI, Murcia: CSIC, 1997, doc. LXXVII.

19 MARAVALL, J. A., El concepto de España en la Edad Media, Madrid: Centro de Estudios Constitucionales, 1981, p. 263.

20 CATALÁN, D., Gran Crónica de Alfonso XI... vol. I, p. 295 y 401.

21 El cronista pone en boca del monarca meriní la idea de dominar toda la Cristiandad. Ibid., vol. II, p. 304.

22 GOÑI GAZTAMBIDE, J., Historia de la bula de cruzada en España, Vitoria: Editorial del Seminario, 1958, 2 vols. La cita la recoge O’CALLAGHAN, J. F., op.cit., p. 19 El recurso a la Cruzada no sólo fue usado por los monarcas para legitimar su poder y ganarse el favor de la curia papal, ya que tener la condición de cruzado también sirvió a muchos nobles como protección en sus enfrentamientos a la Monarquía. Véase RODRÍGUEZ LÓPEZ, A.: "Légitimé royale et discours de la croisade en Castille. XIIe-XIIIe siècles", Journal des Savants, 2004 / I, pp. 129-163. 
pañas del monarca estuvieron acompañadas de esa vitola, pero, independientemente de ese carácter formal, la mera existencia de un estado islámico era inaceptable, por lo que cualquier guerra contra él se inscribía en los planes divinos, respondía a $\mathrm{Su}$ voluntad $^{23}$.

El sentimiento religioso de la guerra rezuma en toda la crónica. Esta motivación, si no real, sí era socialmente aceptable ${ }^{24}$, por ello se critica que "los genoveses ovieron sienpre manera de ayudar a quien les diese dineros, e sobre esto non catavan christiandad nin otro bien ninguno" 25 .

Aunque hay alguna mención anterior, por ejemplo al mencionar el paraíso que aguardaba a los muertos en el enfrentamiento del río Palmones $(1333)^{26}$, desde que la acción se sitúa en los prolegómenos de la célebre batalla, el discurso se tiñe de invocaciones sacras constantes: declaración de la campaña como Cruzada por parte del Papa; calificación del oponente como "enemigos de la Santa Cruz"; enaltecimiento de los prisioneros cristianos que, tras el desastre de la flota del Almirante Jofre Tenorio, habían preferido el martirio a la conversión; los soldados que iban a Tarifa tomaron la señal de la cruz y ordenaron su vida y hacienda como buenos cristianos; o la invocación a Santiago antes de la batalla y la promesa de remisión de las penas a todos los que murieran en combate ${ }^{27}$.

La visión religiosa de la guerra no se limitaba a las motivaciones que aducían los poderes políticos para justificar distintas acciones bélicas, sino que impregnó la concepción misma de ésta hasta conferirle el carácter de ordalía. Las crónicas gustaban de priorizar lo excepcional a lo cotidiano, por ello resaltaron la importancia del elemento imaginario y sobrenatural $^{28}$. De este modo, las batallas adquierieron un carácter teológico y providencial, eran un juicio en el que se dirimía qué bando contaba con el favor divino.

La crónica reproduce esta idea. El rey granadino planteó el combate de esta manera para terminar de convencer al emperador meriní, Abu l-Hasan: dos reyes contra otros dos, una ley contra otra, y que ayude Dios a la mejor. Poco después se consideraba a Dios “juzgador de la batalla"29.

El combate del Salado responde a una ordalía porque presentaba un esquema litúrgico: había un acto de reconciliación y una misa antes del combate y un acto de agradecimiento después ${ }^{30}$, como puede seguirse en el relato del texto. Al tener la solemnidad de una liturgia, el hecho sólo podía ser viril, por lo que había una ausencia de mujeres en el bando del bien ${ }^{31}$. Esto contrastaba con el otro lado, donde el monarca benimerín había venido acompañado de sus esposas. La mujer tiene un papel de señuelo o tentación. Aunque esta

\footnotetext{
23 GARCÍA FITZ, F., Edad Media. Guerra e ideología..., p. 196.

24 GARCÍA FITZ, F., Las Navas de Tolosa..., p. 180.

25 CATALÁN, D., Gran Crónica de Alfonso XI..., vol. II, p. 324.

26 Ibid., vol. II, pp. 41-42.

27 Ibid., vol. II, pp.343, 368-370, 377, 385 y 410.

28 PANIAGUA LOURTAU, A. B.: op. cit., p. 420.

29 CATALÁN, D., Gran Crónica de Alfonso XI..., vol. II, pp. 402 y 404.

30 PANIAGUA LOURTAU, A. B.: op. cit., pp. 428-429.

31 Además de esta analogía con la interpretación que da Duby, resulta curioso el que la condesa de Flandes sea representada como una bruja con poderes adivinatorios, al igual que una de las esposas de Abu 1-Hasan, aunque la segunda sí acertó con sus predicciones. Véase DUBY, G., El domingo de Bouvines, 24 de julio de 1214, Madrid: Alianza, 1988, pp. 25-26.
} 
idea no se desarrolló en este momento, según la crónica, la lujuria había sido poco antes la perdición de Abu Malik, hijo de Abu 1-Hasan, pues fue sorprendido en su campamento mientras pasaba la noche con una cautiva cristiana ${ }^{32}$.

La noción de ordalía y la de Cruzada iban perfectamente ensambladas en la batalla del Salado, pero no siempre ocurrió así. El desastre de la Vega de Granada de 1319 se interpretaba como un castigo divino (¡el propio monarca granadino fue quien lo invocó!) por romper las treguas suscritas con el reino islámico, pero, según el propio cronista, esa campaña había sido auspiciada por el Papa, quien obligó al Infante Pedro a pasar a la ofensiva en virtud de las bulas de Cruzada concedidas ${ }^{33}$. Esta contradicción muestra cómo el uso de motivos religiosos, pese a ser continuo, no era sistemático ni absolutamente homogéneo.

Ambas ideas no sólo justificaban una política militar concreta, sino que contribuían a modelar una imagen regia determinada: Alfonso XI cumplía el paradigma ideal de príncipe cristiano, pues defendía valerosamente la fe. Esta noción se reforzaba al presentar la actitud del monarca en las luchas con los otros reinos peninsulares, pues decidió detener los ataques sobre Navarra o liberar prisioneros portugueses por "piedad cristiana" 34 . Pese a ser conflictos legítimos, al actuar en defensa propia, el Onceno se mostró magnánimo y era representado como el defensor de los cristianos, independientemente del reino al que pertenezcan.

Siendo innegable su existencia, no hay acuerdo entre los distintos autores a la hora de calificar la importancia de la religión en el proceso expansionista cristiano (ni en el relato del mismo). En tanto algunos la consideran esencial y característica, otros la subordinan ante la importancia de la idea de Reconquista. Tampoco hay consenso a la hora de datar su origen, pues mientras determinados historiadores se han remontado a las montañas asturianas, es situado en el siglo XI en otras investigaciones. También, por otra parte, hay quienes estiman que se desarrolló por la influencia musulmana en la Península ${ }^{35}$.

A diferencia de las crónicas francesas o cruzadas, las castellanas no concibieron el conflicto cristiano-musulmán únicamente en términos de Cruzada o "guerra total", salvo el breve período en torno a la batalla de Las Navas de Tolosa ${ }^{36}$. Con el enemigo se pactaba y se esperaba un comportamiento similar, no era un contrario absoluto ${ }^{37}$. Del mismo modo, y pese a las connotaciones teológicas evidentes que le imprimía a la guerra, don Juan Manuel también explicó estas luchas por las diferencias de tipo territorial ${ }^{38}$.

32 CATALÁN, D., Gran Crónica de Alfonso XI..., vol. II, p. 276-282.

33 Ibid., vol. I, pp. 309-310.

34 Ibid., vol. II, p. 115 y pp. 182-183.

35 Para profundizar en el estado de la cuestión véase CANTARINO, V.: op. cit., pp. 82-83 y para ahondar en el debate de tradicionalistas y pluralistas me remito a O'CALLAGHAN, J. F., op. cit., p.20.

36 BARKAI, R., Cristianos y musulmanes en la España Medieval (El enemigo en el espejo), Madrid: Rialp, 1991, pp. 291-292.

37 GARCÍA FITZ, F., "La conquista de Andalucía en la cronística castellana del siglo XIII: las mentalidades historiográficas en los relatos de la conquista”, en Cabrera, E. (coord.), Andalucía entre Oriente y Occidente (1236-1492). Actas del V Coloquio Internacional de Historia Medieval de Andalucía, Córdoba: Diputación Provincial de Córdoba, 1988, p. 59.

38 GARCÍA FITZ, F., "La guerra en la obra de Don Juan Manuel”, en López de Coca Castañer, J. E. (ed.), Estudios sobre Málaga y el Reino de Granada en el V Centenario de la Conquista, Málaga: Servicio de Publicaciones de la Diputación Provincial, 1987, pp. 67-69. 


\section{LA RECONQUISTA}

Durante décadas ha sido el tema de mayor controversia y debate en el medievalismo hispano. Su definición clásica, enunciada por Sánchez Albornoz ${ }^{39}$, fue cuestionada por Barbero y Vigil ${ }^{40}$, quienes rechazaban el continuismo de la herencia visigótica en los, escasamente romanizados, pueblos norteños. Desde entonces ha habido un variado elenco de publicaciones que criticaban el término, intentaban definirlo o acotarlo o, simplemente, lo rechazaban de plano $^{41}$. En la actualidad, se entiende como una ideología justificativa del avance territorial y de la conquista de los territorios detentados por los musulmanes ${ }^{42} \mathrm{O}$ simplemente, y por comodidad, como la expansión de los reinos cristianos peninsulares ${ }^{43}$.

Cualquier acción militar que aspirase a recomponer un orden previo era considerada aceptable ${ }^{44}$. Por tanto, los distintos cronistas vincularon la monarquía visigótica con los reinos de Asturias-León-Castilla para justificar el derecho a recuperar el territorio que antes había pertenecido a aquéllos y reponer su autoridad. La primera vez que apareció este término fue en la Crónica Profética, la Crónica de Albeda y en la Crónica de Alfonso III, que se proponía continuar la Historia de los Reinos Godos de Isidoro de Sevilla y sirvió de base para los autores de los siglos posteriores ${ }^{45}$.

Las obras siguientes ahondaron en esta tendencia, hasta llegar a su plenitud y madurez en época de Alfonso X, con la Estoria de España, ya escrita en romance y que se valía de recursos como la poesía épica ${ }^{46}$. La cronística de Alfonso XI se insertó en esta línea y prosiguió en la repetición de esta idea.

Tal como se mencionó anteriormente, cuando el rey iba a dirigir en persona su primera campaña contra Granada, el cronista se detuvo en relatar los orígenes del reino musulmán y explicar los motivos que llevan al conflicto ${ }^{47}$. La labor del Onceno se vinculó con la de anteriores monarcas en esta tarea insoslayable. Como se ha mencionado anteriormente, éste era un recurso ideológico frecuente. En la Estoria de España, Fernando III impelía a su hijo a que prosiguiese su política expansiva, advirtiéndole que si perdía tierras o vasallos sería peor rey que lo fue é $1^{48}$. El mismo texto relataba la recuperación de las campanas de

39 Véase SÁNCHEZ ALBORNOZ, C., España, un enigma histórico, Madrid: Edhasa, 2000 ( $1^{\circ}$ edición 1956), 2 vols.

40 BARBERO, A. y VIGIL, M., Sobre los orígenes sociales de la Reconquista, Barcelona: Ariel, 1974 y La formación del feudalismo en la Península Ibérica, Barcelona: Crítica, 1978.

41 Me remito a otros autores, quienes han desarrollado esta cuestión de manera más pormenorizada LOMAX, D., La Reconquista, Barcelona: Crítica, 1984, p. 10 y, sobre todo, GONZÁLEZ JIMÉNEZ, M., “¿Reconquista? Un estado de la cuestión", en E. BENITO RUANO (coord.), Tópicos y realidades de la Edad Media (I), Madrid, 2000, pp. 155-178 y GARCÍA DE CORTÁZAR, J. Á. et al., Organización social del espacio en la España medieval. La Corona de Castilla en los siglos VIII a XV, Barcelona: Ariel, 1985, p. 13.

42 GONZÁLEZ JIMÉNEZ, M., op. cit., p. 162.

43 GARCÍA FITZ, F., Las Navas de Tolosa..., p. 397.

44 GARCÍA FITZ, F., Edad Media. Guerra e ideología..., p. 54.

45 O’CALLAGHAN, J. F., op. cit., pp. 4 y 7.

46 BARKAI, R., op. cit., pp. 227-230. Para un análisis más profundo sobre la obra alfonsí me remito a los trabajos de Diego Catalán, por ejemplo La Estoria de España de Alfonso X: creación y evolución, Madrid: Universidad Complutense. Seminario Menéndez Pidal, 1992.

47 CATALÁN, D., Gran Crónica de Alfonso XI..., vol. I, p. 401.

48 Lo recoge POWERS, J. F., A Society Organized for War. The Iberian Municipal Militias in the Central Middle Ages 1000-1284, Berkeley y Los Angeles: University of California Press, 1988, p. 68. 
Santiago, tomadas por Almanzor en 997, tras conquistar Córdoba ${ }^{49}$. Esta forma de vincular el pasado con el presente no era, evidentemente, exclusivamente hispánica: una inscripción en la Puerta de San Nicolás, en Arrás, relacionaba la victoria en Bouvines de Felipe Augusto contra el emperador germano Otón IV con otra, conseguida sobre el primero del mismo nombre, doscientos cincuenta años antes. El motivo de estas continuas interacciones entre el momento actual y los reinados anteriores era debido a que, en una sociedad tradicional como la medieval, el mejor modo de justificar el presente consistía en mostrarlo como una continuación del pasado ${ }^{50}$.

No obstante, la mayoría de las campañas contra el reino islámico desprendían un hálito de rutina tal que el autor no consideraba necesario revestir de legitimidad esas intervenciones. La batalla del Salado rompe esa monotonía. Es el cenit del reinado.

En primer lugar, se usaba constantemente la voz "España" ${ }^{1}$, algo que no sucedía anteriormente. Castilla concebía los asuntos relativos a Granada, Aragón y Portugal como algo interno ${ }^{52}$, pero, a partir del uso de este término, no es posible inferir un proyecto político concreto. Su aplicación volvía a consistir en evocar el pasado como fuente de legitimación: la desaparecida Hispania romana y visigoda, cuyo heredero directo, Alfonso XI, luchaba por restablecer de nuevo.

La pugna contra los benimerines no era sólo un eslabón más en esta expansión, misión inherente a todos los reyes, sino que fue el mayor desafío que habían afrontado los monarcas castellanos hasta entonces, pues ni su padre ni su abuelo se enfrentaron a tamaña amenaza ${ }^{53}$. La intervención meriní en la Península se presentó como una invasión análoga a la del 711. El peligro que se cernía sobre la Península era igual que el padecido por los visigodos siglos atrás. Se pone en boca de Abu 1-Hasan esta referencia, pues afirmaba que volvería a ganar España como lo hicieron sus antecesores ${ }^{54}$. De esta manera se situaba a cada bando con su origen, con un pasado que hacía inteligible el presente y condicionaba el futuro. Pero el discurso no se quedó ahí, el narrador consideraba que la victoria del Salado era la más importante que habían conseguido nunca los reyes de Castilla, más aún que la de Las Navas de Tolosa, pues el Onceno venció sin ayuda foránea, no tuvo tiempo de preparar el ejército concienzudamente y las cifras de combatientes y bajas enemigas eran mayores ${ }^{55}$. Así pues, Alfonso XI no sólo siguió la trayectoria de sus antepasados, sino que la elevó hasta su máximo esplendor.

A través de las nociones de Cruzada y Reconquista, la confrontación militar con el Islam en la Península era, a todos los efectos, una acción legítima y justificada ${ }^{56}$. No obstante, hay un tercer elemento que se aprecia en la cronística como detonante capaz de provocar y explicar una intervención militar: la defensa del honor.

49 Mencionado en MACKAY, A.. La España de la Edad Media. Desde la frontera hasta el Imperio (1000-1500), Madrid: Cátedra, 2000, pp. 72-73.

50 MARTÍNEZ, P.: "La historia como vehículo político...”, p. 216.

51 CATALÁN, D., Gran Crónica de Alfonso XI..., vol. II, pp. 318-319, 359, 389 y 424.

52 DIAZ MARTÍN, L. V.: "Castilla, 1280-1360: ¿Política exterior o relaciones accidentales?”, en VV. AA., Génesis medieval del Estado Moderno: Castilla y Navarra (1252-1370), Valladolid: Ámbito, 1987, p. 126

53 Aunque en esta ocasión se refiere al ataque sobre Gibraltar, el ejemplo resulta extrapolable pues es un episodio distinto pero dentro de la misma lucha. CATALÁN, D., Gran Crónica de Alfonso XI..., vol. II, pp. 37.

54 Ibid., vol. II, pp. 424-425.

55 Ibid., vol. II, pp. 439-441.

56 GARCÍA FITZ, F., Edad Media. Guerra e ideología..., p. 217. 


\section{EL HONOR}

Para don Juan Manuel, el motivo inexcusable para ir a la guerra era evitar la deshonra: "todas las otras cosa deve omne ante sofrir que començar guerra salvo la desonra", pues "la muerte, que es la mas grave cosa que puede seer, debe omne ante sofrir que pasar et sofrir desonra",57.

La importancia del honor también estaba presente en la Crónica, hasta el punto de considerar lógico que se desencadenase una guerra por motivos de honra. Alfonso XI actuaba en base a esa motivación. Eludir un posible combate podía ir en merma de su prestigio, por lo que, tras perder Gibraltar, el rey decidió comparecer allí no sólo por si podía recuperarla, sino "porque era mas su honrra llegar al castillo". Eso también sucedió en 1340, pues Alfonso XI estaba dispuesto a presentar batalla pese la ostensible inferioridad numérica con la que contaba. Del mismo modo, el Onceno se negó a huir de noche ante un posible ataque porque menguaría su honra ${ }^{58}$.

De manera aún más clara y directa, la invasión benimerín respondería, entre otras razones, al deseo de venganza personal de Abu l-Hasan tras la muerte de su hijo en su campaña de 1339 en suelo peninsular ${ }^{59}$. De todos modos, no se transmitía una imagen positiva de este personaje, pues en la batalla aparecía como un cobarde, perdiendo su honor pues "por miedo de la muerte olvido verguença del mundo, e con mengua de los suyos començo de fuyr, e dexo sus mugeres e sus hijos en su rreal en poder ageno" ${ }^{\circ 0}$. El contraste entre las imágenes de un monarca y otro es evidente.

Asimismo, esta idea también apareció en otras monarquías occidentales coetáneas. Eduardo III chocó con cierta resistencias en el Parlamento para costear el ejército inglés en el continente entre 1339 y 1340, por lo que, para obtener la financiación necesaria, sus agentes afirmaron que "nuestro señor el Rey necesitaba ser asistido con una gran ayuda, o quedaría deshonrado para siempre y sus tierras a ambos lados del mar en gran peligro" De esta manera, se entremezclaban argumentos pragmáticos con otros ideológicos. Fórmulas similares serían utilizadas por el Onceno en reuniones de Cortes, pero, como ya se mencionó con anterioridad, es una reflexión que escapa a los propósitos del presente trabajo.

No obstante, la noción de honor se veía mitigada y, en parte, diluida por el ideal de "rey administrador", heredero del derecho justinianeo. En su Chronicon Mundi, Lucas de Tuy establecía que las virtudes regias eran obedecer a Dios, la defensa de la fe católica, mantener el reino en paz, practicar la justicia y luchar contra los enemigos ${ }^{62}$. En cambio, en la Baja Edad Media se priorizaba rodearse de consejeros capaces y ejercer el gobierno con sabiduría, habilidad política, prudencia y, después, justicia ${ }^{63}$.

\footnotetext{
57 MACPHERSON, I. R. y TATE, R. B. (eds.), op. cit., p. 207.

58 CATALÁN, D., Gran Crónica de Alfonso XI..., vol. II, pp. 39, 68-69, 349-352 у 379-382.

59 Ibid., vol. II, pp. 287-289.

60 Ibid., vol. II, pp. 431-432.

61 Mencionado en KEEN, M. (ed.), Historia de la guerra en la Edad Media, Madrid: Antonio Machado Libros, 2005, pp. 195-196.

62 RODRÍGUEZ LÓPEZ, A., "History and Topography for the Legitimisation of Royalty in three Castilian Chronicles", Majestas, 12 (2004), p. 72.

63 MARTÍNEZ, P., "La historia como vehículo político...”, p. 218 Para un análisis más detallado de la cuestión véase GUENÉE, B., Histoire et Culture historique dans l’Occident Medieval, París: Aubier Montaigne, 1980 y States and Rulers in Later Medieval Europe, Oxford y New York: Basil Blackweel, 1985.
} 
De esta manera, y aunque el monarca pudiera ver su honor lesionado, debía tomar decisiones que fueran en pro del reino, pues es la cabeza del mismo. La crónica conjugaba estas tendencias utilizando un recurso frecuente: el contraste de pareceres entre los consejeros, guiados por la prudencia, y el rey, cuya actuación aparecía dictaminada por el honor. Por ejemplo, Alfonso XI frenó su ímpetu y decidió no atacar el real musulmán en 1333 pues sus consejeros le advirtieron de posibles celadas, recordándole los males devenientes a Castilla de una hipotética muerte del soberano. De igual modo, aunque el Onceno quería continuar la guerra y recuperar Gibraltar, tuvo que ir contra su honor y firmar una tregua por el bien de Castilla, que padecía numerosos ataques ${ }^{64}$.

Alfonso XI aparecía en todo momento como un buen rey con un alto sentido del honor. Estas virtudes personales, unidas a su devoción cristiana y su énfasis en la lucha contra el Islam, situaban al monarca en las tres coordenadas habituales de los héroes hispanos ${ }^{65}$. Se inscribía en el mismo modelo ideal que Fernando III, Alfonso III o el legendario Pelayo ${ }^{66}$.

\section{CONCLUSIONES}

Los mensajes proyectados por la clase dominante sublimaban la actividad bélica, pues justificaba su posición social ${ }^{67}$. Las crónicas son buena muestra de ello, pues transmitían una imagen de la guerra determinada, que no era gratuita ni mucho menos inocente.

En ese sentido, cabe preguntarse hasta qué punto ese grupo, en este caso la Monarquía, era capaz de transmitir sus visiones y representaciones del mundo al resto de la sociedad ${ }^{68}$. Como afirma García Fitz, "los argumentos ideológicos si no son movilizadores, sí se espera, al menos, que lo sean" ${ }^{69}$. Es decir, había un reconocimiento social, independientemente de su eficacia.

De esta forma, mientras que el enemigo comenzaba la guerra por ansias de poder o riqueza ${ }^{70}$, Alfonso XI nunca alegaba argumentos políticos o económicos, sino que sus campañas estaban guiadas por más altas razones, siendo los ideales de Cruzada y Reconquista aquéllos esgrimidos de manera más frecuente.

Este último sería el motivo más propio y característico de la monarquía castellana, pues era su fuente de legitimación más directa, al justificar, no sólo su política militar, sino su

\footnotetext{
64 CATALÁN, D., Gran Crónica de Alfonso XI..., vol. II, p. 62 y p. 67.

65 BARKAI, R., op. cit., p. 45.

66 Resulta curioso cómo las referencias al rey Santo (el que ganó Sevilla, Córdoba y Jaén), son muy prolijas en el texto, mientras que Alfonso VIII y la batalla de Las Navas sólo aparecen para comparar y agrandar la gesta del Salado. Podría interpretarse que el esquema teológico-ordalístico que aparece en la Estoria de España de este monarca (derrota en Alarcos-abandono de su concubina judía y arrepentimiento-victoria en Las Navas) no casa bien con la imagen que quiere moldear el Onceno de sí mismo, pues supondría achacarle la pérdida de Gibraltar y cuestionar abiertamente la figura de Leonor de Guzmán. Las comparaciones de Alfonso XI con sus predecesores es un tema muy interesante pero que excede los límites de este trabajo, por lo que me limito a apuntar esta hipótesis.

67 FERNÁNDEZ DE LARREA Y ROJAS, J. A., Guerra y sociedad en Navarra durante la Edad Media, Bilbao: Universidad del País Vasco, 1992, p. 11.

68 GARCÍA FITZ, F., "La conquista de Andalucía en la cronística castellana del siglo XIII...”, p. 52

69 GARCÍA FITZ, F., Edad Media. Guerra e ideología..., p. 16.

70 En el texto las intenciones de dominar y poblar "la rica España" son patentes CATALÁN, D., Gran Crónica de Alfonso XI..., vol. II, pp. 318-319.
} 
propia razón de ser. La Reconquista concebía una visión del pasado en la que éste entroncaba con el presente y se proyectaba hacia el futuro (idealizado). Cada generación debía dejar su impronta en la consecución de ese destino ${ }^{71}$.

Aquí reside uno de los pilares del éxito de la función legitimadora de la historiografía medieval, pues conseguía atenuar las distancias entre ese pasado remoto y el presente que había que consolidar. "Su eficacia no reside en la racionalidad de su contenido, sino en la coherencia de su relato, que tan bien se aviene con las motivaciones de quienes las promocionaron y con las inquietudes de sus lectores"72.

Pero las intenciones del Onceno no se quedaron ahí. Mientras que Alfonso X escribió sus obras para convencer a la sociedad de la justeza de los planes que albergaba, su bisnieto mandó elaborar las crónicas una vez su proyecto político había sido desarrollado, pues la nobleza estaba sometida y la invasión benimerín frenada ${ }^{73}$. De esta manera, encargó la redacción de un texto cuya principal intención no era justificar sus actuaciones, especialmente las militares (aunque también lo haga), la finalidad era ensalzar su figura, no como un mero continuador de la tarea de sus mayores, sino para presentarse como el mejor monarca de un linaje ya memorable ${ }^{74}$.

\section{BIBLIOGRAFÍA}

AURELL, J., "El nuevo medievalismo y la interpretación de los textos históricos”, Hispania, 224 (2006), pp. 809-831.

BARBERO, A. y VIGIL, M., La formación del feudalismo en la Península Ibérica, Barcelona, Crítica, 1978.

- Sobre los orígenes sociales de la Reconquista, Barcelona: Ariel, 1974

BARKAI, R., Cristianos y musulmanes en la España Medieval (El enemigo en el espejo), Madrid, Rialp, 1991.

CANTARINO, V., “The Spanish Reconquest: A Cluniac Holy War against Islam?”, en Islam and the medieval West. Aspects of Intercultural relations: papers presented at the Ninth Annual Conference of the Center for Medieval and Early Renaissance Studies State University of New York at Binghamton, Khalil I. Semaan (ed.), Albany, State University of New York Press, 1980, pp. 82-109.

CATALÁN, D., Gran Crónica de Alfonso XI, Madrid: Gredos, 1977, dos vols.

DIAZ MARTÍN, L. V., "Castilla, 1280-1360: ¿Política exterior o relaciones accidentales?” en Génesis medieval del Estado Moderno: Castilla y Navarra (1252-1370), Valladolid, Ámbito, 1987, pp. 125-147.

DUBY, G., El domingo de Bouvines, 24 de julio de 1214, Madrid: Alianza, 1988.

71 GARCÍA FITZ, F., Las Navas de Tolosa..., p. 402.

72 AURELL, J., op. cit., p. 822.

73 MARTÍNEZ, P., "La historia como vehículo político...”, pp. 218-219. Sobre el fortalecimiento de la Monarquía y la expansión del poder real durante el reinado de Alfonso XI véase Estepa Díez, C., "La monarquía castellana en los siglos XIII-XIV. Algunas consideraciones", Edad Media. Revista de Historia, 8 (2007), pp. 79-98 y "The Strengthening of Royal Power in Castile under Alfonso XI", en Alfonso, I., Kennedy, H. y Escalona, J. (eds.), Building Legitimacy. Political Discourses and Forms of Legitimation in Medieval Societies, LeidenBoston: Brill, 2004, pp. 179-222.

74 MARTÍNEZ, P., Ibid., p. 229. 
ESTEPA DÍEZ, C., "La monarquía castellana en los siglos XIII-XIV. Algunas consideraciones", Edad Media. Revista de Historia, 8 (2007), pp. 79-98 .

- "The Strengthening of Royal Power in Castile under Alfonso XI", en Building Legitimacy. Political Discourses and Forms of Legitimation in Medieval Societies, Alfonso, I., Kennedy, H. y Escalona, J. (eds.), Leiden-Boston, Brill, 2004, pp. 179-222.

FERNÁNDEZ DE LARREA Y ROJAS, J. A., Guerra y sociedad en Navarra durante la Edad Media, Bilbao, Universidad del País Vasco, 1992.

GARCÍA DE CORTÁZAR, J. Á. et al., Organización social del espacio en la España medieval. La Corona de Castilla en los siglos VIII a XV, Barcelona: Ariel, 1985.

GARCÍA FITZ, F., Edad Media. Guerra e ideología. Justificaciones jurídicas y religiosas, Madrid, Sílex, 2003.

- "La conquista de Andalucía en la cronística castellana del siglo XIII: las mentalidades historiográficas en los relatos de la conquista", en Andalucía entre Oriente y Occidente (1236-1492). Actas del V Coloquio Internacional de Historia Medieval de Andalucía, Cabrera, E. (coord.), Córdoba, Diputación Provincial de Córdoba, 1988, pp. 51-61.

- "La guerra en la obra de Don Juan Manuel”, en Estudios sobre Málaga y el Reino de Granada en el V Centenario de la Conquista, López de Coca Castañar, J. E. (ed.), Málaga, Servicio de Publicaciones de la Diputación Provincial, 1987, pp. 55-72.

- Las Navas de Tolosa, Madrid, Ariel, 2005.

GÓMEZ REDONDO, F., Historia de la prosa medieval castellana. I La creación del discurso político: el entramado cortesano, Madrid, Cátedra, 1998.

GONZÁLEZ JIMÉNEZ, M., “¿Re-conquista? Un estado de la cuestión”, en Tópicos y realidades de la Edad Media, Benito Ruano, E. (coord.), Madrid, 2000, vol. I, pp. 155-178.

GOÑI GAZTAMBIDE, J., Historia de la bula de cruzada en España, Vitoria, Editorial del Seminario, 1958, 2 vols.

GUENÉE, B., Histoire et Culture historique dans l'Occident Medieval, París: Aubier Montaigne, 1980.

- States and Rulers in Later Medieval Europe, Oxford y New York, Basil Blackweel, 1985.

KEEN, M. (ed.), Historia de la guerra en la Edad Media, Madrid, Antonio Machado Libros, 2005.

LOMAX, D., La Reconquista, Barcelona, Crítica, 1984.

MACKAY, A., La España de la Edad Media. Desde la frontera hasta el Imperio (1000-1500), Madrid, Cátedra, 2000.

MACPHERSON, I. R. y TATE, R. B. (eds.), El libro de los Estados, Madrid, Castalia, 1991.

MARAVALL, J. A., El concepto de España en la Edad Media, Madrid, Centro de Estudios Constitucionales, 1981.

MARTÍNEZ, P., "La Crónica y la Gran Crónica de Alfonso XI: dos versiones ideológicas del reinado de Alfonso XI", Hispanic Research Journal: Iberian and Latin American Studies, vol. 1, n ${ }^{\circ} 1$ (2000), pp. 43-56.

- "La historia como vehículo político: la figura real en la Crónica de Alfonso XI", Espacio, tiempo y forma. Serie III, 13 (2000), pp. 215-231. 
O’CALlaGHAN, J. F., Reconquest and Crusade in Medieval Spain, Philadelphia, University of Pennsylvania, 2003.

PANIAGUA LOURTAU, A. B., "Consideraciones sobre los musulmanes en la Gran Crónica de Alfonso XI', en Historia, tradiciones y leyendas en la frontera: IV estudios de Frontera: congreso celebrado en Alcalá la Real en noviembre de 2001: homenaje a Don Enrique Toral y Peñaranda, Toro Cevallos, F. y Rodríguez Molina, J. (coords.), Jaén: Diputación Provincial, 2002, pp. 417-430.

POWERS, J. F., A Society Organized for War. The Iberian Municipal Militias in the Central Middle Ages 1000-1284, Berkeley y Los Angeles, University of California Press, 1988.

RODRÍGUEZ LÓPEZ, A., "History and Topography for the Legitimisation of Royalty in three Castilian Chronicles", Majestas, 12 (2004), pp. 1-21.

- "Légitimé royale et discours de la croisade en Castille. XIIe-XIIIe siècles", Journal des Savants, 2004 / I, pp. 129-163.

ROJAS GABRIEL, M., "La batalla en la Edad Media y su contexto estratégico. El choque del Salado (1340), reexaminado" en Tarifa en la Edad Media, González Jiménez, M. (ed.), Tarifa, Excmo Ayuntamiento de Tarifa, 2005, pp. 147-172.

SÁNCHEZ ALBORNOZ, C., España, un enigma histórico, Madrid, Edhasa, 2000 ( $1^{\circ}$ edición 1956), 2 vols.

VEAS ARTESEROS, F., Colección de documentos para la historia del Reino de Murcia. VI Documentos de Alfonso XI, Murcia, CSIC, 1997. 